Jurnal Ilmu Ilmu Agribisnis: Journal of Agribusiness Science, 9(2), Mei 2021

\title{
ANALISIS EFISIENSI PEMASARAN PRODUKSI JAGUNG DI KECAMATAN BANDAR SRIBHAWONO KABUPATEN LAMPUNG TIMUR
}

\section{(Analysis of Marketing Efficiency of Corn in Bandar Sribhawono District of East Lampung Regency)}

\author{
Asih Titiana, Ktut Murniati, Eka Kasymir
}

Jurusan Agribisnis, Fakultas Pertanian, Universitas Lampung, Jl. Prof. Dr. Soemantri Brojonegoro No. 1 Bandar Lampung 35145, e-mail: ktut.murniati@fp.unila.ac.id

\begin{abstract}
This study aims to analyze the efficiency of corn marketing. The research method used is a survey method. Data collection was carried out in Bandar Sribhawono District of East Lampung Regency in January - March 2019. Farmer respondents were chosen randomly and marketing agency respondents were taken by following the marketing flow. Data used are primary and secondary data. The analysis method used is the S-C-P (Structure, Conduct, Performance) model. The results showed that the corn marketing system in Bandar Sribhawono Sub-district has not been efficient, because the market structure faced by farmers was the oligopsonistic market structure, market behavior shows that farmers are still disadvantaged and act as price takers, there was one marketing channel with producer share (PS) below 55 percent, high marketing margin and profit margin ratio (RPM) does not spread evenly.
\end{abstract}

Key words: corn, efficiency, marketing

\section{PENDAHULUAN}

Jagung merupakan tanaman pangan jenis serealia dan tanaman terpenting setelah padi dan gandum. Hampir seluruh masyarakat mengenal jagung. Di Indonesia beberapa daerah, seperti Madura dan Nusa Tenggara, pernah mengkonsumsi jagung sebagai sumber pangan utama (Kementerian Pertaian 2016).

Lampung merupakan salah satu provinsi penghasil jagung yang berkontribusi terhadap produksi jagung nasional sebesar 8,49 persen. Persentasi ini menjadikan Provinsi Lampung menduduki posisi ketiga secara nasional. Posisi pertama dan kedua diduduki oleh Provinsi JawaTimur dan Jawa Tengah dengan persentasi produksi masing masing, yaitu 30,70 persen dan 14,00 persen (BPS 2017).

Provinsi Lampung memiliki rata - rata luas panen sebesar 24.619,8 ha dengan pruduktivitas 5,27 ton/ha. Kabupaten Lampung Timur menempati posisi pertama dengan produktivitas jagung sebesar 5,54 ton/ha dan menjadi kabupaten yang selalu menanam jagung disetiap tahunnya. Luas lahan jagung yang dimiliki setiap kecamatan di Kabupaten Lampung Timur sangat beragam. Kecamatan Bandar Sribawono merupakan penghasil jagung terbesar di Kabupaten Lampung Timur dengan luas lahan sebesar 22.667 ha dan nilai produktivitas sebesar 5,68 ton/ha (BPS 2017).
Kecamatan Bandar Sribhawono mengalami produksi yang fluktuatif yaitu tahun 2014 sampai tahun 2017. Pada tahun 2014 rata - rata produksi jagung sebesar $12.475,7 \mathrm{~kg}$ dengan harga yang diterima petani sebesar Rp2.353,9/kg. Tahun 2015 rata - rata produksi jagung sebesar $11.869,4 \mathrm{~kg}$ dengan harga yang diterima petani sebesar $\mathrm{Rp} 2.239,5 / \mathrm{kg}$. Tahun 2016 rata - rata produksi jagung sebesar $11.1555,0 \mathrm{~kg}$ dengan harga yang diterima petani sebesar Rp1.964,0/kg, sedangkan pada tahun 2017 rata - rata produksi jagung sebesar $12.8749 \mathrm{~kg}$ dengan harga yang diterima petani sebesar Rp2.353,9/kg. Data tersebut mejelaskan bahwa tahun 2014 sampai 2016 rata rata harga yang diterima petani mengalami penurunan, ini disebabkan rendahnya posisi petani dalam rantai pemasaran jagung, sehingga petani tidak dapat melakukan tawar - menawar harga kepada pedagang pengumpul yang membeli jagung.

Salah satu sebab rendahnya harga yang diterima petani yaitu panjangnya rantai pemasaran yang ada, setiap lembaga pemasaran yang terlibat akan melakukan fungsi pemasaran, sehingga mengakibatkan semakin besar biaya pemasaran yang dapat mempengaruhi efisiensi pemasaran. Keterlibatan pedagang perantara akan menyebabkan harga yang diterima petani produsen dan yang dibayarkan oleh konsumen akhir (pabrik) berbeda, hal ini dapat mempengaruhi efisiensi pemasaran. Oleh karena itu, sistem pemasaran 
jagung sangat penting untuk diketahui guna melihat efisien atau tidaknya kegiatan tersebut.

Berdasarkan permasalahan di atas, maka perlu dilakukan penelitian mengenai efisiensi pemasaran usahatani jagung di Kecamatan Bandar Sribawono Kabupaten Lampung Timur. Tujuan penelitian ini adalah untuk menganalisis efisiensi sistem pemasaran jagung di Kecamatan Bandar Sribhawono Kabupaten Lampung Timur, dilihat dari struktur pasar, perilaku pasar, dan keragaan pasar.

\section{METODE PENELITIAN}

Metode penelitian yang digunakan pada penelitian ini adalah survei. Penelitian ini dilakukan di Kecamatan Bandar Sribawono Kabupaten Lampung Timur. Pemilihan lokasi penelitian ini dilakukan secara sengaja (purposive). Responden petani jagung yang dipilih adalah petani jagung yang tergabung dalam kelompok tani. Responden petani jagung dipilih secara acak (Simple Random Sampling) untuk petani. Menurut Newman dalam Silaen dan Widiyono (2013), untuk penelitian deskriptif, sampel sebesar 10 persen dari populasi merupakan jumlah paling minimum, dan untuk penelitian korelasional, jumlah sampel paling sedikit 30 , di dalam penelitian ini terdapat populasi sebanyak 453 petani jagung.

Berdasarkan pendapat Newman dalam Silaen dan Widiyono (2013) maka sampel yang didapatkan sebanyak 45 petani jagung. Untuk menentukan pedagang responden dengan cara mengikuti alur pemasaran jagung yang ada di Desa Sadar Sriwijaya dapat dilihat pada Tabel 1 .

Tabel 1. Sebaran jumlah responden lembaga pemasaran jagung di Kecamatan Bandar Sribhawono Kabupaten Lampung Timur, 2019

\begin{tabular}{lll}
\hline No. & Lembaga Pemasaran & Jumlah \\
\hline 1. & Pedagang Pengumpul & 9 \\
2. & Pedagang Besar & 4 \\
3. & Konsumen Akhir (Pabrik) & $3^{*}$ \\
\hline
\end{tabular}

Keterangan :

* : Tidak diwawancarai

Jenis data yang digunakan dalam penelitian ini adalah data primer dan data sekunder. Data Penelitian ini dilakukan dengan wawancara dan pengamatan langsung di lapang. Teknik pengumpulan data primer diperoleh melalui wawancara langsung dengan petani dan pedagang responden menggunakan kuesioner (daftar pertanyaan) yang telah disiapkan. Data sekunder diperoleh dari lembaga atau instansi terkait, jurnal, skripsi, publikasi, dan pustaka lainnya yang terkait dan relevan dengan penelitian ini.

Menurut Hasyim (2012) pengukuran efisiensi pemasaran dapat dilakukan dengan melalui teknik S-C-P, yaitu market structure, market conduct, dan market perfomance. Struktur pasar (market structure) merupakan gambaran hubungan antara penjual dan pembeli yang dilihat dari jumlah lembaga pemasaran, diferensiasi produk, dan kondisi keluar masuk pasar (entry condition). Perilaku pasar (market conduct) merupakan gambaran tingkah laku lembaga pemasaran dalam menghadapi struktur pasar. Keragaan pasar (market performance) merupakan gambaran gejala pasar yang tampak akibat interaksi antara struktur pasar (market structure) dan perilaku pasar (market conduct).

Analisis keragaan pasar menggunakan beberapa indikator, yaitu : (1) Saluran pemasaran merupakan suatu jalur yang dilalui oleh arus barang-barang dari produsen ke perantara dan akhirnya sampai ke konsumen. (2) Pangsa produsen atau produsen share (PS) bertujuan untuk mengetahui bagian harga yang diterima petani (produsen), yang dinyatakan dalam bentuk persentasi (Hasyim, 2012). Apabila PS semakin tinggi, maka kinerja pasar semakin baik dari sisi produsen. Pangsa produsen dirumuskan sebagai :

$\mathrm{PS}=\frac{P_{f}}{P_{r}} \times 100 \%$

Keterangan :

Ps $=$ Bagian harga yang diterima produsen

$\mathrm{Pf}=$ Harga di tingkat produsen

$\operatorname{Pr}=$ Harga di tingkat konsumen

Marjin pemasaran merupakan perbedaan antara harga di tingkat produsen dengan harga di tingkat pengecer (Hasyim 2012). Secara matematis, total marjin pemasaran dirumuskan sebagai berikut:

$M j i=\sum m j i$, atau $M j i=\operatorname{Pr}-P f$.

Penyebaran marjin pemasaran dapat dilihat berdasarkan persentase keuntungan terhadap biaya pemasaran (ratio profit margin) pada masingmasing lembaga pemasaran, yang dirumuskan sebagai berikut:

$R P M=\frac{\pi i}{b t i}$ 
Keterangan :

$$
\begin{aligned}
\mathrm{mji}= & \text { marjin pada lembaga pemasaran tingkat } \\
& \text { ke-i } \\
\mathrm{Mji}= & \text { total marjin pada satu saluran pemasaran } \\
\mathrm{Psi}= & \text { harga jual pada lembaga pemasaran } \\
& \text { tingkat ke- } \mathrm{i} \\
\mathrm{Pbi}= & \text { harga beli pada lembaga pemasaran } \\
& \text { tingkat ke- } \mathrm{i} \\
\mathrm{bti}= & \text { biaya pemasaran lembaga pemasaran } \\
& \text { tingkat ke- } \mathrm{i} \\
\pi \mathrm{i} & =\begin{array}{l}
\text { keuntungan lembaga pemasaran tingkat } \\
\text { ke-i }
\end{array} \\
\mathrm{i} \quad= & 1,2,3, \ldots, \ldots \mathrm{n}
\end{aligned}
$$

\section{HASIL DAN PEMBAHASAN}

\section{Karakteristik Responden}

Umur petani jagung berkisar antara 35-61 tahun, menghasilkan rata - rata sebesar 45,33 tahun yang termasuk ke dalam umur produktif. Tingkat pendidikan petani mayoritas (40\%) tamat Sekolah Menengah Pertama (SMP). Pengalaman berusahatani jagung petani mayoritas $(27 \%)$ antara 8-15 tahun. Luas lahan yang dimiliki petani antara 1,5-3 hektar dengan rata-rata 2,1 hektar lahan milik sendiri tidak ada sewa lahan. Petani jagung di Kecamatan Bandar Sribhawono menghasilkan rata - rata produski sebesar $13.105,55 \mathrm{~kg} / \mathrm{ha}$ dalam keadaan jagung basah (ada bonggolnya) pada musim tanam ketiga.

Mayoritas $(77 \%)$ pedagang pengumpul berumur antara 44-52 tahun dengan rata - rata 49,59 tahun yang termasuk kedalam umur produktif. Tingkat

Pendidikan pedagang pengumpul $(44,44 \%)$ tamat SMA, rata - rata pedagang pengumpul sudah menjalankan usahanya selama 19,11 tahun, sedangkan pada pedagang besar rata - rata berumur 53,75 tahun dengan tingkat pendidikan (75\%) tamat SMA.

Petani jagung berada di Desa Sadar Sriwijaya Kecamatan Bandar Sribhawono Kabupaten Lampung Timur, semua petani jagung menjual hasil panennya kepada pedagang pengumpul dengan cara pedagang pengumpul datang langsung ke lokasi panen jagung. Disini petani hanya mengeluarkan biaya panen jagung dan jagung dijual dalam keadaan basah kepada pedagang pengumpul.

Pedagang pegumpul berjumlah sembilan orang, enam diantaranya berada di Kecamatan Bandar
Sribawono dan tiga lainnya berada di Kecamatan Way Jepara. Pedagang pengumpul mengeluarkan biaya transportasi, biaya tenaga kerja untuk mengangkut jagung dari kendaraan ke gudang penyimpanan, dan biaya pengemasan atau karung untuk memudahkan memindahkan jagung. Fasilitas yang dimiliki pedagang pengumpul, gudang penyimpanan dan transportasi seperti mobil truk. Pedagang pengumpul menjual jagung dalam keadaan basah ke pedagang besar.

Pedagang besar berjumlah empat orang, dua berada di luar Kabupaten Lampung Timur tepatnya di Kabupaten Lampung Selatan dan dua lainnya berada di Kabupaten Lampung Timur tepatnya di Kecamatan Sribawono dan Way Jepara. Biaya yang dikeluarkan pedagang besar lumayan cukup banyak diantaranya, biaya transportasi untuk membawa jagung ke konsumen akhir (pabrik), biaya konsumsi, biaya tenaga kerja, biaya pengeringan dan biaya pengerontokan. Pedagang besar melakukan pemeliharaan seperti pengeringan jagung dan pengerontokan jagung sehingga jagung yang djual pedagang besar dalam keadaan jagung pipil dan semua jagung dijual ke konsumen akhir (pabrik). Fasilitas yang dimiliki pedagang besar yaitu, gudang penyimpanan jagung, alat pengering jagung, alat pengerontok jagung dan transportasi seperti mobil truk.

Konsumen akhir (pabrik) pada penelitian ini tidak diwawancarai dikarenakan (pabrik) melakukan proses produksi lain sehinnga produk yang dihasilkan bukan jagung lagi tetapi dalam bentuk berbagai macam pakan.

\section{Analisis Efisiensi Pemasaran Jagung}

\section{Struktur pasar (Market structure)}

Struktur pasar jagung di daerah penelitian dapat di identifikasikan dengan cara melihat hubungan antara penjual dan pembeli yang dilihat dari jumlah lembaga pemasaran yang terlibat, sifat produk dan kondisi keluar masuk pasar (entry condition). Terdapat empat lembaga pemasaran dalam saluran pemasaran jagung di Kecamatan Bandar Sribhawono, yaitu petani, pedagang pengumpul, pedagang besar, dan konsumen akhir (pabrik). Struktur pasar yang dihadapi oleh para pelaku pasar dalam pemasaran jagung diuraikan sebagai berikut :

Struktur pasar yang dihadapi oleh petani jagung adalah struktur pasar oligopsoni, artinya jumlah petani jagung sebagai penjual lebih banyak 
dibandingkan dengan pedagang pegumpul, pedagang besar dan pabrik sebagai pembeli. Informasi pasar diperoleh dari sesama petani, khusus untuk informasi harga diperoleh dari lembaga perantara jumlah responden petani sebanyak 45 orang.

Struktur pasar yang dihadapi pedagang pengumpul jagung adalah struktur pasar oligopsoni, karena jumlah pedagang pengumpul yang menjual jagung lebih banyak dibandingkan dengan jumlah pedagang besar dan kosumen akhir (pabrik) sebagai pembeli. Hambatan masuk pasar bagi pedagang pengumpul terletak pada sulitnya menjaga pasokan dalam pendistribusian jagung tersebut, karena jumlah produksi jagung yang fluktuatif. Proses penentuan harga didasarkan pada tawar menawar dengan informasi harga diperoleh dari sesama pedagang pengumpul atau langsung dari pedagang besar. Jumlah pedagang pengumpul sebanyak sembilan orang responden.

Struktur pasar yang dihadapi oleh pedagang besar adalah struktur pasar oligopsoni, dimana jumlah pedagang besar yang menjual jagung lebih banyak dibandingkan dengan jumlah konsume kahir (pabrik) yang membeli jagung. Hambatan masuk pasar bagi pedagang besar terletak pada modal yang harus dikeluarkan untuk membeli jagung. Komoditas yang diperjualbelikan bersifat homogen yaitu jagung. Proses penentuan harga ditentukan langsung oleh konsume akhir (pabrik) yang akan membeli jagung dari pedagang besar. Jumlah pedagang besar sebanyak empat orang responden.

Konsumen akhir disini yaitu pabrik yang menentukan harga jagung yang berlaku saat itu. Terdapat tiga konsumen akhir (pabrik) yaitu PT Charoen Pokhand Indonesia berlokasi di kabupaten Lampung Selatan, PT New Hope berlokasi di Kabupaten Lampung Selatan dan PT Japfa Comfeed unit Way Jepara berlokasi di Kabupaten Lampung Timur.

Hasil penelitian menunjukkan bahwa semua lembaga pemasaran yaitu petani, pedagang pengumpul, dan pedagang besar serta pabrik yang terlibat dalam usahtani jagung bebas untuk keluar masuk suatu daerah untuk transaksi pembelian jagung tidak terdapat adanya pembagian wilayah dalam pembelian jagung oleh pedagang pengumpul dan pedagang besar. Struktur pasar yang dihadapi oleh semua pedagang yaitu semua struktur pasar oligopsoni. Hal ini sesuai dengan penelitian Virginia, Arifin dan Suryani (2019) sistem agribisnis jagung di Kecamatan Adiluwih
Kabupaten Pringsewu juga meghasilkan kesimpulan penelitian yang sama yaitu, pedagang boleh keluar masuk pasar, tidak ada pembagian wilayah dan struktur pasar yang terjadi adalah struktur pasar oligopsoni.

\section{Perilaku Pasar (Market conduct)}

Perilaku pasar dapat diketahui dengan melakukan pengamatan terhadap perilaku lembaga pemasaran yaitu meliputi kegiatan pembelian dan penjualan, penentuan harga, pembayaran serta kerjasama di antara berbagai lembaga pemasaran. Unsur perilaku pasar tersebut adalah :

Proses penentuan harga jagung di lokasi penelitian dilakukan berdasarkan harga yang berlaku di pasaran, petani jagung menerima harga (price taker) yang telah ditentukan oleh lembaga perantara yang di pilih, dengan ini petani tidak mungkin mempengaruhi harga komoditas yang diperjualbelikan. Konsumen akhir (pabrik) memiliki kekuatan tertinggi dalam menentukan harga beli kepada pedagang di level bawahnya. Hasil penelitian ini berbeda dengan Amelia, Hasyim dan Situmorang (2019) menghasilkan proses penentuan harga cengkeh antara petani dengan pedagang besar didasarkan atas harga yang berlaku di pasaran, sedangkan penelitian ini harga yang diterima petani bukanlah harga yang berlaku dipasarkan karena komoditi yang diperjual belikan adalah jagung dalam keadaan basah bukan jagung dalam kering pipil. Proses tercapainya kesepakatan harga antara petani dan pedagang berlangsung cepat.

Di Kecamatan Bandar Sribhawono rata - rata harga yang diterima petani jagung sebesar $\mathrm{Rp} 1.855,56 / \mathrm{kg}$ dengan rata - rata produksi $13.105,55 \mathrm{~kg} / \mathrm{ha}$ jagung basah, sedangkan harga beli yang diterima konsumen akhir (pabrik) adalah sebesar Rp4.296/kg dengan rata - rata produksi menjadi $17.380,48 \mathrm{~kg}$ jagung pipil kering. Maka terjadi penyusutan produksi dari petani sampai ke konsumen akhir (pabrik) sebesar 8.690,24 kg.

Rata - rata produksi usahatani jagung sebesar $13.105,55 \mathrm{~kg} / \mathrm{ha}$ dengan harga yang diterima petani $\mathrm{Rp} 1.855,56 / \mathrm{kg}$, maka penerimaan yang diterima petani sebesar Rp24.318.134,40/ha, sedangkan produksi jual dari pedagang besar ke konsumen akhir (pabrik) sebesar 8.690,24 kg/ha dengan harga beli konsumen akhir (pabrik) sebesar Rp4.295,56/kg maka dihasilkan penerimaan pedagang besar sebesar Rp37.329.447.30/ha. Selisih harga yang sangat jauh antara petani 
produsen dengan pedagang besar disebabkan oleh setiap lembaga pemasaran yang terlibat melakukan fungsi pemasaran sehingga mengakibatkan semakin besar biaya pemasaran yang dikeluarkan sehinnga menekan harga petani produsen.

Berdasarkan penelitian yang dilakukan oleh Rahmi (2019) analisis usahatani dan pemasaran jagung, harga yang diterima petani sebesar Rp2.600/kg harga ini lebih tinggi dibandingkan dengan daerah penelitian, ini dikarenakan pada penelitian Rahmi (2019) petani menjual jagung dalam bentuk pipilan sedangkan pada penelitian jagung dalam bentuk tongkol.

Terdapat dua sistem pembayaran yang dilakukan oleh lembaga pemasaran jagung di Kecamatan Bandar Sribhawono, yaitu sistem pembayaran tunai, dilakukan oleh para pedagang pengumpul yang mempunyai modal yang memadai, sehingga mampu membayar secara tunai kepada penjual dan sistem bayar kemudian (bayar tunda). Sistem pembayaran ini dilakukan oleh lembaga perantara yaitu pedagang besar dan konsumen akhir (pabrik).

\section{Keragaan pasar (market performance)}

Saluran pemasaran, merupakan suatu jalur yang dilalui oleh arus barang dari produsen ke perantara dan akhirnya sampai ke konsumen. Lembaga pemasaran jagung di Kecamatan Bandar Sribhawono dapat dilihat pada Gambar 1.

Kecamatan Bandar Sribawono Kabupaten Lampung Timur hanya terdapat satu saluran pemasaran. Semua petani responden menjual jagungnya ke pedagang pengumpul, kemudian pedagang pengumpul menjual seluruh jagung ke pedagang besar, selajutnya pedagang besar menjual seluruh jagungnya ke konsumen akhir (pabrik). Hal ini sejalan dengan penelitian Lestari, Hasyim dan Kasymir (2017) analisis usahatani dan efisiensi pemasaran kopi (coffea sp) di Kecamatan Pulau Panggung Kabupaten Tanggamus, terdapat satu saluran pemasaran, yaitu petani menjual ke pedagang pengumpul, lalu pedagang pengumpul ke pedagang besar dan terakhir ke eksportir.

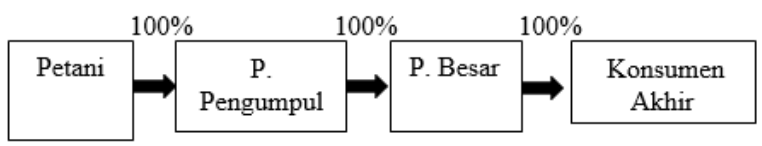

Gambar 1. Saluran pemasaran jagung di Kecamatan Bandar Sribhawono Kabupaten Lampung Timur, 2019
Berbeda dengan penelitian Sazmi, Haryono dan Suryani (2018) analisis pendapatan dan efisiensi pemasaran ikan patin terdapat tiga saluran pemasaran, yaitu saluran pertama petani, pedagang pengumpul, pedagang besar dan konsumen, ssluran kedua petani, pedagang pengumpul, pedagang pengecer, dan konsumen, saluran ketiga petani, pedagang pengumpul, pedagang besar, pedagang pengecer dan konsumen.

Pangsa produsen atau produsen share (PS) bertujuan untuk mengetahui bagian harga yang diterima petani (produsen), yang dinyatakan dalam bentuk persentasi (Hasyim,2012). Semakin tinggi pangsa produsen menjadi indikator bahwa pemasaran semakin efisien. Hasil dari penelitian ini pangsa produsen jagung sebesar 43,20\%. Hal ini terjadi karena rata- rata harga jual jagung di tingkat petani adalah Rp1.855,56/kg, sedangkan harga jual pedagang besar sebesar Rp4.296/kg. Dari hasil wawancara kepada pedagang besar, tingginya harga jual jagung mereka disesuaikan dengan biaya yang mereka keluarkan terutama penyusutan jagung dikarenakan pengeringan dan hilangnya bonggol jagung.

Hasil tersebut sesuai dengan penelitian Meilisa dan Aida (2017) studi pendapatan usahatani dan pemasaran jagung manis yang menghasilkan nilai pangsa produsen sebesar $40 \%$ yang artinya kegiatan pemasaran jagung belum efisien.

Marjin pemasaran dan rasio profit marjin, salah satu indikator yang digunakan untuk menentukan efisiensi suatu sistem pemasaran. Marjin pemasaran berpengaruh secara langsung terhadap pembentukan harga di tingkat petani produsen sehingga mempunyai peranan penting dalam menentukan besar kecilnya pendapatan petani. Besarnya bagian harga yang diterima produsen, marjin pemasaran, marjin keuntungan (profit marjin), dan ratio profit marjin pemasaran jagung di Kecamatan Bandar Sribhawono Kabupaten Lampung Timur dapat dilihat pada Tabel 2.

Harga jual jagung pedagang pengumpul sebesar Rp2.198,89/kg, sedangkan harga beli jagung pedagang pengumpul sebesar Rp1.855,56/kg, sehinnga didapatkan margin pemasaran pedagang pengumpul sebesar Rp343,33/kg.

Harga jual jagung pedagang besar sebesar Rp4.296/kg, sedangkan harga beli jagung pedagang besar sebesar Rp2.198,89/kg, sehingga didapatkan margin pemasaran pedagang besar $\mathrm{Rp} 2.096,67 / \mathrm{kg}$. 
Jurnal Ilmu Ilmu Agribisnis: Journal of Agribusiness Science, 9(2), Mei 2021

Tabel 2. Analisis marjin pemasaran jagung di Kecamatan Bandar Sribhawono Kabupaten Lampung Timur, 2019

\begin{tabular}{|c|c|c|c|c|}
\hline \multicolumn{5}{|c|}{ Saluran Pemasaran } \\
\hline No & Uraian & Satuan & Nilai & $\begin{array}{c}\text { Share } \\
(\%)\end{array}$ \\
\hline 1 & \multirow{2}{*}{\multicolumn{2}{|c|}{$\begin{array}{l}\text { Harga Jual Petani } \\
\text { Pedagang Pengumpul }\end{array}$}} & $1.855,56$ & 43,2 \\
\hline \multirow[t]{10}{*}{2} & & & & \\
\hline & a. Harga Beli & $\mathrm{Rp} / \mathrm{kg}$ & $1.855,56$ & 43,2 \\
\hline & $\begin{array}{l}\text { b. Marjin } \\
\text { Pemasaran }\end{array}$ & $\mathrm{Rp} / \mathrm{kg}$ & 343,33 & 7,98 \\
\hline & $\begin{array}{l}\text { c. Biaya } \\
\text { Pemasaran }\end{array}$ & $\mathrm{Rp} / \mathrm{kg}$ & 193,11 & 4,49 \\
\hline & $\begin{array}{l}\text { Biaya } \\
\text { Transportasi }\end{array}$ & $\mathrm{Rp} / \mathrm{kg}$ & 112,33 & 2,61 \\
\hline & Tenaga Kerja & $\mathrm{Rp} / \mathrm{kg}$ & 50,78 & 1,18 \\
\hline & Pengemasan & $\mathrm{Rp} / \mathrm{kg}$ & 30 & 0,69 \\
\hline & $\begin{array}{l}\text { d. Margin } \\
\text { Keuntungan }\end{array}$ & $\mathrm{Rp} / \mathrm{kg}$ & 150,22 & 3,49 \\
\hline & $\begin{array}{l}\text { e. Rasio Profit } \\
\text { Margin }\end{array}$ & $\%$ & & 77,79 \\
\hline & f. Harga Jual & $\mathrm{Rp} / \mathrm{kg}$ & $2.198,89$ & 51,18 \\
\hline \multirow[t]{12}{*}{3} & \multicolumn{4}{|l|}{ Pedagang Besar } \\
\hline & a. Harga Beli & $\mathrm{Rp} / \mathrm{kg}$ & $2.198,89$ & 51,18 \\
\hline & $\begin{array}{l}\text { b. Marjin } \\
\text { Pemasaran }\end{array}$ & $\mathrm{Rp} / \mathrm{kg}$ & $2.096,67$ & 48,8 \\
\hline & c. Biaya & $\mathrm{Rp} / \mathrm{kg}$ & 522,11 & 12,15 \\
\hline & BiayaTransportasi & $\mathrm{Rp} / \mathrm{kg}$ & 116 & 2,7 \\
\hline & Konsumsi & $\mathrm{Rp} / \mathrm{kg}$ & 54 & 1,25 \\
\hline & Tenaga Kerja & $\mathrm{Rp} / \mathrm{kg}$ & 51 & 1,18 \\
\hline & Pengeringan & $\mathrm{Rp} / \mathrm{kg}$ & 251,11 & 5,84 \\
\hline & Pengerontokan & $\mathrm{Rp} / \mathrm{kg}$ & 50 & 1,21 \\
\hline & $\begin{array}{l}\text { d. Margin } \\
\text { Keuntungan }\end{array}$ & $\mathrm{Rp} / \mathrm{kg}$ & $1.574,56$ & 36,65 \\
\hline & $\begin{array}{l}\text { e. Rasio Profit } \\
\text { Margin }\end{array}$ & $\%$ & & 301,57 \\
\hline & f. Harga Jual & $\mathrm{Rp} / \mathrm{kg}$ & $4.296,00$ & 100 \\
\hline \multirow[t]{2}{*}{4} & \multicolumn{4}{|c|}{ Konsumen Akhir/Pabrik } \\
\hline & Harga Beli & $\mathrm{Rp} / \mathrm{kg}$ & $4.296,00$ & 100 \\
\hline
\end{tabular}

Margin pemasaran pedagang pegumpul sebesar Rp343,33 sedangkan biaya pemasaran jagung pedagang pengumpul Rp193,11 maka margin keuntungan yang diperoleh pedagang pengumpul sebesar Rp150,22/kg. Biaya pemasasran yang di keluarkan pedagang pengumpul, yaitu biaya transportasi, biaya tenaga kerja dan biaya pengemasan. Margin keuntungan dan biaya pemasaran sudah diketahhui maka nilai ratio profit margin (RPM) pedagang pengumpul sebesar Rp77,79/kg artinya setiap Rp1,00 biaya yang dikeluarkan akan menghasilkan keuntungan sebesar Rp77,79/kg.

Margin keuntungan yang diperoleh pedagang besar sebesar Rp1.574,56/kg, sedangkan biaya pemasaran yang dikeluarkan sebesar $\mathrm{Rp} 2.096,67 / \mathrm{kg}$, sehingga diperoleh ratio profit margin (RPM) pedagang besar sebesar $\mathrm{Rp} 301,57 / \mathrm{kg}$ artinya setiap $\mathrm{Rp} 1,00$ biaya yang dikeluarkan akan menghasilkan keuntungan sebesar Rp301,57/kg. Jika dilihat dari ratio profit margin (RPM) pedagang pengumpul dan pedagang besar, selisih ratio profit margin (RPM) lembaga pemasaran jagung di Kecamatan Bandar Sribhawono Kabupaten Lampung Timur tidak merata, maka sistem pemasaran tersebut dikatakan tidak efisien. Hasil tersebut sesuai dengan penelitian Ali, Situmorang dan Murniati (2017) analisis efisiensi pemasaran kubis di Kecamatan Gisting Kabupaten Tanggamus juga menghasilkan nilai ratio profit margin (RPM) tidak merata sehingga dapat dikatakan bahwa semua saluran pemasaran yang ada di Kecamatan Gisting Kabupaten Tanggamus tidak efisien.

Menurut Azzaino (1983), yang menyatakan bahwa nilai ratio profit margin (RPM) yang relatif menyebar merata pada berbagai tingkat lembaga pemasaran merupakan cerminan dari sistem pemasaran yang efisien. Hasil dari penelitian yang menghasilkan nilai ratio profit margin (RPM) yang tidak merata maka sudah dipastikan semua saluran pemasaran tidak efisien.

\section{KESIMPULAN}

Sistem pemasaran jagung di Kecamatan Bandar Sribhawono Kabupaten Lampung Timur belum efisien, karena : Struktur pasar dalam sistem pemasaran jagung di Kecamatan Bandar Sribhawono menghadapi struktur pasar oligopsonistik di tingkat petani. Penentuan dan pembentukan harga yang terjadi cukup sederhana, metode pembayaran kepada petani sistem tunai. Keragaan pasar dalam sistem pemasaran jagung menunjukkan pangsa produsen masih rendah yaitu $43,20 \%$ dan marjin pemasaran cenderung tinggi (terutama di tingkat pedagang besar), dan nilai Ratio Profit Margin tidak merata.

\section{DAFTAR PUSTAKA}

Ali FM, Situmorang S dan Murniati K. 2017. Analisis efisiensi pemasaran kubis Di Kecamatan Gisting Kabupaten Tanggamus. Jurnal Ilmu Ilmu Agribisnis, 5(3): 258-266. http://jurnal.fp.unila.ac.id/index.php/JIA /article/view/1638/1464 Diakses Tanggal 1 Mei 2010

Amelia SM, Hasyim AI dan Situmorang S. 2019. Efisiensi sistem pemasaran cengkeh (Syzygium Aromaticum) di Kabupaten Pesisir Barat. JIIA, 7(2): 187-194. http://jurnal.fp.unila.ac.id/index.php/JIA/ article/view/ 3380/2581 Diakses Tanggal 22 
April 2020.

Azzaino Z. 1983. Pengantar Tataniaga Pertanian. Diktat Kuliah Fakultas Pertanian Universitas Lampung. Universitas Lampung. Bandar Lampung.

BPS [Badan Pusat Statistik] 2017. Provinsi Lampung Dalam Angka 2017.https://lampung.bps.go.id/publicatio n/2017/08/11/9f3e06a09ebc3306f2f013c0/ provinsi-lampung-dalam-angka2017.html. [22 April 2019]

Hasyim AI. 2012. Tataniaga Pertanian. Universitas Lampung. Bandar Lampung.

Kementerian Pertanian. 2016. Outlook Jagung 2016. Pusat Data dan Sistem Informasi Pertanian. Jakarta.

Lestari O, Hasyim AI, dan Kasymir E. 2017. Analisis usahatani dan efisiensi pemasaran kopi (Coffea Sp) di Kecamatan Pulau Panggung Kabupaten Tanggamus. Jurnal Ilmu Ilmu Agribisnis, 5(1):1-8 http://jurnal.fp.unila.ac.id/i ndex.php/JIA/article/view/1668/1494.. $\quad$ [22 April 2020]

Meilisa R dan Aidam S. 2017. Studi Pendapatan Usahatani Dan Pemasaran Jagung Manis (Zea Mays L. Saccharata) Di Desa Manunggal
Daya Kecamatan Sebulu Kabupaten Kutai Kartanegara. Jurnal Ekonomi Pertanian \& Pembangunan, 14 (2), 26-38. http://agb.faperta.unmul.ac.id/ wpcontent/uploads/2017/03/3-sy-idarixky-mstudy-pendapatan-usatanipemasaranjagung.pdf.. [20 April 2020].

Rahmi C. 2019. Analisis Usahatani Dan Pemasaran Jagung (Studi Kasus : Desa Pamah, Kecamatan Tanah Pinem, Kabupaten Dairi). Skripsi. Universitas Sumatra Utara. Medan.

Sazmi RM, Haryono D dan Surysni A. 2018. Analisis pendapatan dan efisiensi pemasaran ikan patin di kecamatan seputih raman Kabupaten Lampung Tengah. JIIA, 6(2): 133141. http://jurnal.fp.unila.ac.id/index.php/JIA/ article/view/2778/2323. [01 Februari 2020]

Silaen S dan Widiyono. 2013. Metodologi penelitian sosial untuk penulisan skripsi dan tesis. In Media. Jakarta.

Virginia S, Arifin B dan Suryani A. 2019. Sistem agribisnis jagung di Kecamatan Adiluwih Kabupaten Pringsewu. Jurnal Ilmu Ilmu Agribisnis, $\quad 7(4): \quad 458-\quad 462$. http://jurnal.fp.unila.ac .id/index.php/JIA/article/viewFile/3860/28 28 [1 Mei 2020]. 